\title{
GPC2 wt Allele
}

National Cancer Institute

\section{Source}

National Cancer Institute. GPC2 wt Allele. NCI Thesaurus. Code C123851.

Human GPC2 wild-type allele is located in the vicinity of 7q22.1 and is approximately $8 \mathrm{~kb}$ in length. This allele, which encodes glypican-2 protein, plays a role in the localization of heparin sulfate on cell membranes. 